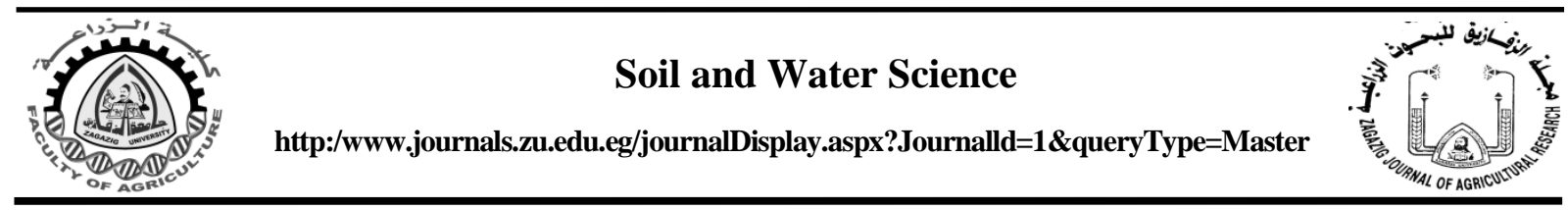

\title{
REMOVAL OF LEAD FROM POLLUTED WATER BY USING CLAY MINERALS
}

\author{
Wafaa M. Hashesh ${ }^{1 *}$, F.M. Habib ${ }^{2}$, M.M. Wahba ${ }^{1}$, Esmat H.A. Noufal ${ }^{2}$ and \\ Nesren H. Abou-Baker ${ }^{1}$
}

1. Soils and Water Use Dept., Nat. Res. Cent., Cairo, Egypt

2. Soil Dept., Fac. Agric. Benha Univ., Egypt

Received: 14/ 8/2017 ; Accepted: 10/ 9/2017

\begin{abstract}
Clay minerals or natural materials such as zeolite play an important role in reducing the potential hazards of toxic elements. They cannot completely destroy heavy metals but can only be transformed from a single phase oxidation or organic compound to another. In this study clay minerals used to reduce the hazardous of lead on aqueous solutions. The used minerals were zeolite, bentonite and montmorillonite. Each mineral was applied at the rates of 1,3 and $5 \%(W / V)$ of waste water. The concentrations used of lead were 60,120 and 180ppm. The results observed that wherever increased the rate of the clay minerals added to the contaminated liquid has increased the amount adsorbed of lead. Therefore, the highest amount adsorbed of lead was obtained with $5 \%$ of soil minerals in all cases. The highest amount of lead adsorbed was obtained with zeolite at the rate of $5 \%$ (177 ppm) followed by montmorillonite and bentonite (165 and $145 \mathrm{ppm}$ ), respectively. There is a positive relationship with both the amount adsorbed of lead and the rate of soil mineral added to the solution of contaminated. On the other hand, the highest lead removal efficiency was found as about $98.7 \%$ with the rate of $5 \%$ zeolite mineral. Whereas, the lowest lead removal efficiency was found as about 39\% with the rate of $1 \%$ bentonite mineral. The arrangement of the soil minerals ability to adsorb lead was followed this order: zeolite > montmorillonite $>$ bentonite. This study suggests that using of available natural materials could be an economic and promising alternative solution in contaminated water to minimize hazards of heavy metals. The clay minerals are suitable materials for heavy metal removal from the industrial waste water.
\end{abstract}

Key words: Heavy metals, lead, adsorption, zeolite, montmorillonite, bentonite.

\section{INTRODUCTION}

Removing heavy metals demands high energy or advanced operational requirements. A number of conventional technologies such as coagulation, precipitation, ion-exchange, electrochemical methods, membrane processes, extraction, biosorption, and adsorption have been considered for the treatment of contaminated waste water (Kwon et al., 2010; Wang and Peng, 2010). In the last few years many researchers have studied new techniques to remove contaminants from soils (Saber et al., 2012). In other words, Mojiri et al. (2015) reported that, for heavy metals removal from landfill leachate and domestic waste water, employing the powdered zeolite method was more effective than the application of the traditional activated carbon.

For the importance role of zeolite in reducing harmful hazarded of lead, Hasanabadi et al. (2015) indicated that zeolite was able to decrease the amount of uptake and transmission of lead and cadmium in plant and with decreasing the harmful effects of these elements cause to increase the growth traits, protein and uptake of nutrient in plant. So, zeolite can be used in order to decrease heavy metals uptake

\footnotetext{
*Corresponding author: Tel.: +201124164512

E-mail address: Wafamohamed482@yahoo.com
} 
such as lead and cadmium and also improvement of growth of plants in polluted areas. Marzieh (2014) stressed on the bentonite play an important role in the adsorbent of the heavy metals, due to the high density and berry color properties and adsorption played an important role in clarifying water and the addition of natural zeolite will reduce, significantly heavy metal pollution.

In this point, Esmaeilpour et al. (2015) studied the effects of adsorbent minerals (bentonite, zeolite and sepiolite) on transfer of some heavy metals (i.e., $\mathrm{Pb}, \mathrm{Zn}$ and $\mathrm{Cd}$ ) from soil to tissues of sunflower. Treatments included: Nonpolluted soil, HM-polluted soil, polluted soil + bentonite, polluted soil + zeolite, and polluted soil + sepiolite. Zeolite addition decreased plant uptake of $\mathrm{Zn}$ and $\mathrm{Cd}$ by about 12 and 0.21 $\mathrm{mg} / \mathrm{kg}$, respectively, while bentonite addition reduced $\mathrm{Pb}$ uptake by about $3.05 \mathrm{mg} / \mathrm{kg}$, without any significant difference for the other treatments. On the other hand, Wahba et al. (2016a) reported that the numerical values of rate constants indicated that in natural materials, zeolite has a sorption capacity to studied PTE's (potential toxic elements) more than bentonite used. Also, according to the kinetic studies, the selectivity of pollutants to be sorbed on clay minerals take the order $\mathrm{Zn}^{+2}>\mathrm{Ni}^{2+}>\mathrm{Pb}^{2}$.

The objective of this experiment was to compare three different soil minerals (zeolite, montmorillonite and bentonite) for their ability to remove hazard of heavy metals.

\section{MATERIALS AND METHODS}

To investigate sorption characteristics of lead onto three clay minerals (montmorillonite, bentonite and zeolite) at rates 1, 3 and 5\% from aqueous solutions, have been done by using batch experiments technique. In three replicates, these clay minerals were weighed into $50 \mathrm{ml}$ centrifuge tubes containing $25 \mathrm{ml}$ of prepared solutions of $\mathrm{Pb}^{+2}\left(60,120\right.$ and $\left.180 \mathrm{mg} \mathrm{l}^{-1}\right)$. The suspensions were shaken mechanically for $24 \mathrm{hr}$. After equilibration, the suspension was centrifuge at $3000-5000 \mathrm{rpm}$ for $10-20 \mathrm{~min}$. Equilibrium concentration of heavy metal (Ce) was determined in $1 \mathrm{ml}$ of supernatant using Atomic Absorption Spectroscopy (AAS). The differences between $\mathrm{Ci}$ "initial concentration of heavy metal" and Ce are assumed to be adsorbed on adsorption materials. The concentration of HMs adsorbed on clay minerals, Cs (mmol $\mathrm{l}^{-1}$ ) is expressed by equation: $\mathrm{Cs}=\mathrm{Ci}-\mathrm{Ce}$. Sorption isotherms curves were obtained by plotting (Cs = conc. of heavy metal adsorbed on clay mineral in $\mathrm{mg} \mathrm{kg}^{-1}$ clay) versus $\mathrm{Ce}=\mathrm{mg}$ per liter).

\section{Heavy Metals}

The stock solutions of metal ions, having concentrations of $1000 \mathrm{mg} \mathrm{l}^{-1}$ were prepared from lead nitrate $\mathrm{Pb}\left(\mathrm{NO}_{3}\right)_{2}$ in $1 \mathrm{mM} \mathrm{HNO} \mathrm{HN}_{3}$ acid. Lead concentration was determined by atomic absorption (Perkin Elmer-AAnalyst 400) as described by Cottenie et al. (1982).

\section{Clay Minerals}

Three types of clay minerals namely; bentonite, montmorillonite and zeolite (clinoptilolite) from ALIX zeolite Company were used in batch experiments. The data in Tables 1,2 and 3 represent some physicchemical properties of these clay materials.

\section{RESULTS AND DISCUSSION}

The laboratory experiment which was conducted to evaluate the impact of some natural minerals on the adsorption of heavy metals to overcome their hazard on contaminated water had resulted in valuable data useful in formations.

Concerning the effect of clay minerals type, results in Table 4 indicate that decreasing order of rate of lead element desorbed was more pronounced in zeolite mineral compared to montmorillonite and bentonite, respectively. It is noteworthy that whenever zeolite rate increased the adsorption amount of lead increased. It's found that the amount adsorbed of lead increased by about $98.7 \%$ at the rate of $5 \%$ zeolite compared to the rate of $1 \%$ at high concentration of lead.

On the other hand, results in Table 4 show that increasing the concentration of lead from 60 to $180 \mathrm{mg} \mathrm{l}^{-1}$, on $5 \%$ of zeolite increased the rate of sorption from 57.2 to $177 \mathrm{mg} \mathrm{l}^{-1}$. In other words, wherever lead concentration increased the adsorption amount of lead increased. Fig. 1 represents the rate process of $\mathrm{Pb}$ adsorbed on clay mineral (zeolite). It shows the highest amount of lead adsorption which was $177 \mathrm{mg} \mathrm{l}^{-1}$ with $5 \%$ of zeolite and the least amount of adsorption which was $44.7 \mathrm{mg} \mathrm{l}^{-1}$ with $1 \%$ of zeolite. 
Table 1. Selected chemical analyses of zeolite mineral used in the study

\begin{tabular}{ccccccccc}
\hline $\mathbf{C E C}$ & Surface area & $\mathbf{p H}$ & $\mathbf{K}_{\mathbf{2}} \mathbf{O}$ & $\mathbf{N a}_{2} \mathbf{O}$ & \multicolumn{4}{c}{ Elements oxides (\%) } \\
\cline { 6 - 9 } $\mathbf{C m o l c ~ K g -}^{\mathbf{1}}$ & $\begin{array}{c}\left.\mathbf{( m}^{\mathbf{2}} \mathbf{g}^{-1}\right) \\
\mathbf{1 : 2 . 5}\end{array}$ & & & $\mathrm{SiO}_{2}$ & $\mathrm{Al}_{2} \mathrm{O}_{3}$ & $\mathrm{Fe}_{2} \mathrm{O}_{3}$ & $\mathrm{CaO}$ \\
\hline 220 & 89.82 & 6.8 & 3.27 & 0.78 & 62.220 & 11.096 & 4.033 & 3.583 \\
\hline
\end{tabular}

Table 2. Particle size distribution and some chemical properties of bentonite

\begin{tabular}{|c|c|c|c|c|c|c|c|c|}
\hline \multicolumn{5}{|c|}{ Particle size distribution (\%) } & \multirow{2}{*}{$\begin{array}{c}\text { pH } \\
1: 2.5\end{array}$} & \multirow{2}{*}{$\begin{array}{c}\text { EC } \\
d S / m\end{array}$} & \multirow{2}{*}{$\begin{array}{l}\mathrm{CaCO}_{3} \\
\mathrm{~g} \mathrm{Kg}^{-1}\end{array}$} & \multirow{2}{*}{$\begin{array}{c}\text { CEC } \\
\text { cmolc Kg }^{-1}\end{array}$} \\
\hline C.sand & F.sand & Silt & Clay & Text.class & & & & \\
\hline 1.1 & 3.8 & 5.3 & 89.8 & Clay & 8.3 & 4.10 & 27.3 & 53.2 \\
\hline
\end{tabular}

Table 3. Selected chemical analyses of montmorillonite mineral used in the study

\begin{tabular}{cccccc}
\hline Color & $\begin{array}{c}\text { Purity } \\
(\mathbf{\%})\end{array}$ & $\begin{array}{c}\mathbf{p H} \\
\mathbf{1 : 2 . 5}\end{array}$ & $\begin{array}{c}\text { Maximum } \\
\text { moisture (\%) }\end{array}$ & $\begin{array}{c}\text { CEC } \\
\mathbf{c m o l c ~ K g}^{-1}\end{array}$ & Chemical structure \\
\hline Off white & $>98$ & 6.8 & 89.82 & 116 & $\begin{array}{c}\text { Natural montmorillonite MMT } \\
\mathrm{M}+\mathrm{y}\left(\mathrm{Al} 2-\mathrm{y} \text { Mgy) (Si4) } \mathrm{O} 10(\mathrm{OH})_{2} \mathrm{nH}_{2} \mathrm{O}\right.\end{array}$ \\
\hline
\end{tabular}

Table 4. Amount of lead removed from aqueous solutions by clay minerals

\begin{tabular}{lcccc}
\hline Clay mineral & $\begin{array}{c}\text { Rate of applied mineral } \\
(\boldsymbol{W} / \boldsymbol{V})\end{array}$ & \multicolumn{3}{c}{ Concentration of the applied Pb (mg/l) } \\
\cline { 3 - 5 } & $1 \%$ & $\mathbf{6 0}$ & $\mathbf{1 2 0}$ & $\mathbf{1 8 0}$ \\
\hline \multirow{3}{*}{ Zeolite } & $3 \%$ & 44 & 88 & 151 \\
& $5 \%$ & 51 & 100 & 162 \\
& $1 \%$ & 57 & 117 & 177 \\
Montmorillonite & $3 \%$ & 35 & 82 & 144 \\
& $5 \%$ & 40 & 93 & 157 \\
Bentonite & $1 \%$ & 45 & 101 & 165 \\
& $3 \%$ & 23 & 61 & 125 \\
& $5 \%$ & 32 & 75 & 133 \\
& & 41 & 92 & 145 \\
\hline
\end{tabular}


Hashesh, et al.

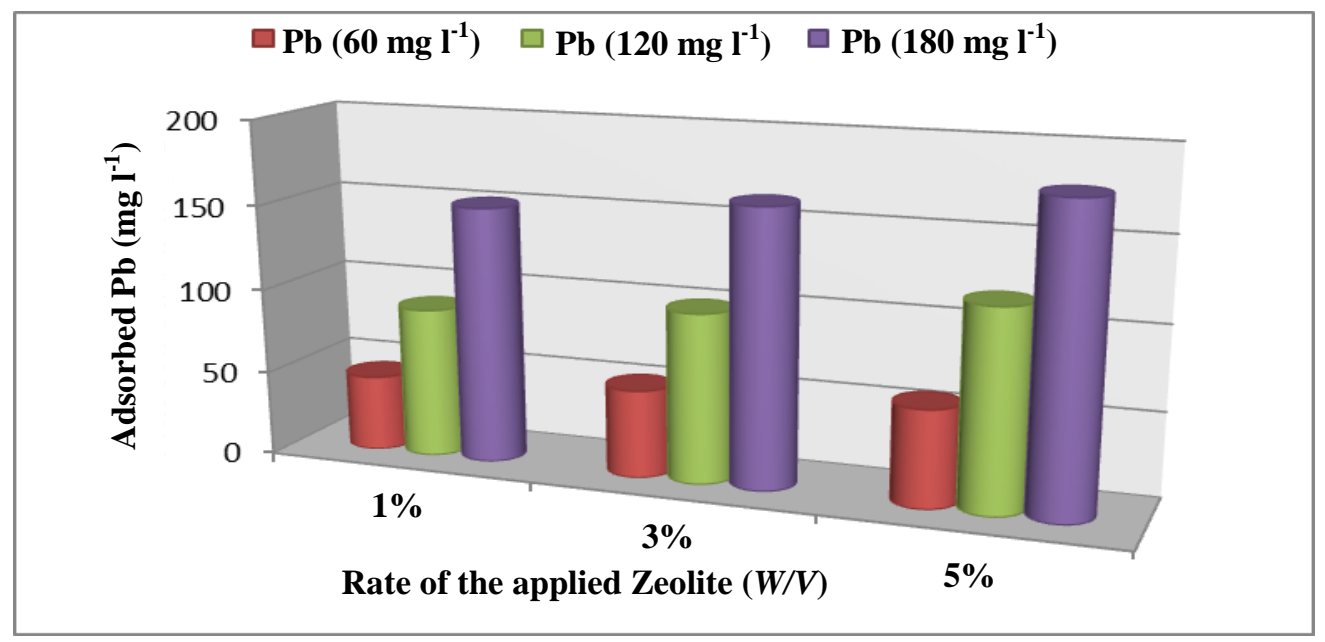

Fig. 1. Lead removal $\left(\mathrm{mg} \mathrm{l}^{-1}\right)$ by diffrent rates of zeolite from aqueous solutions containing different lead levels

For the montmorillonite, results in Table 4 presents that the highest percentage of lead absorption was $80.7 \%$ with the rate of $5 \%$ montmorillonite, while the lowest one was $58.6 \%$ with the rate of $1 \%$ montmorillonite. In the case of increasing the concentration of lead from 60 to $180 \mathrm{mg} \mathrm{l}^{-1}$, the adsorbed amount of lead increased.

Fig. 2 illustrated that the highest amount of lead adsorption was $165 \mathrm{mg} \mathrm{l}^{-1}$ with $5 \%$ of montmorillonite and the least amount of adsorption was $35 \mathrm{mg} \mathrm{l}^{-1}$ with $1 \%$ of montmorillonite. These results are in agreement with Wahba et al. (2012) who found that the adsorption capacity of various heavy metals depends on two main factors 1- The 2: 1 layer silicates as montmorillonite has high surface charges, as a result of isomorphism substitution, compared to 1:1 layered kaolinate. 2- The radius number of the heavy metal has great influence on its adsorption capacity; $\mathrm{Pb}\left(1.81^{*} 10-10 \mathrm{~m}\right)$

For the applying of bentonite mineral with lead, Table 4 reveals that the highest adsorption ratio was $91.7 \%$ with $5 \%$ of bentonite at concentration $180 \mathrm{ppm}$ of lead. On the other hand, the lowest adsorption ratio was 39\% with $1 \%$ of clay mineral at concentration $60 \mathrm{mg} \mathrm{l}^{-1}$ of lead.

Fig. 3 illustrated the quantity of lead adsorbed at different ratios of bentonite with different concentrations of lead. It is noteworthy that wherever bentonite ratio increased the adsorption amount of lead increased. The highest amount of lead adsorbed was $145 \mathrm{mg} \mathrm{l}^{-1}$ with $5 \%$ of bentonite at concentration $180 \mathrm{mg} \mathrm{l}^{-1}$ of lead, while the lowest amount adsorbed of lead was $23.4 \mathrm{mg} \mathrm{l}^{-1}$ with $1 \%$ of bentonite at concentration $60 \mathrm{mg} \mathrm{l}^{-1}$ of lead. These results are in agreement with Wahba et al. (2016b) recorded that bentonite has certain properties as its ability to form thixotrophic gels with water and relatively high cation exchange capacity which allowed the adsorption of heavy metals and reduced their release in soils.

Regarding the effect of zeolite, montmorillonite and bentonite addition on the adsorption of $\mathrm{Pb}^{2+}$ added to water, the adsorption with zeolite was obviously higher than montmorillonite and bentonite, respectively. The results proved that the highest amount adsorbed of lead was $178 \mathrm{mg} \mathrm{l}^{-1}$ with zeolite followed by montmorillonite and bentonite $\left(165,145 \mathrm{mg} \mathrm{l}^{-1}\right)$, respectively.

Regarding the effect of zeolite, montmorillonite and bentonite addition on the adsorption of $\mathrm{Pb}^{2+}$ added to water, the adsorption with zeolite was obviously higher than montmorillonite and bentonite, respectively. The results proved that the highest amount adsorbed of lead was178 $\mathrm{mg} \mathrm{l}^{-1}$ with zeolite followed by montmorillonite and bentonite (165, $\left.145 \mathrm{mg} \mathrm{l}^{-1}\right)$, respectively.

For example, Fig. 4 represented the comparison between quantity of lead desorbed from liquid polluted as affected by zeolite, montmorillonite and bentonite application at three rates. 


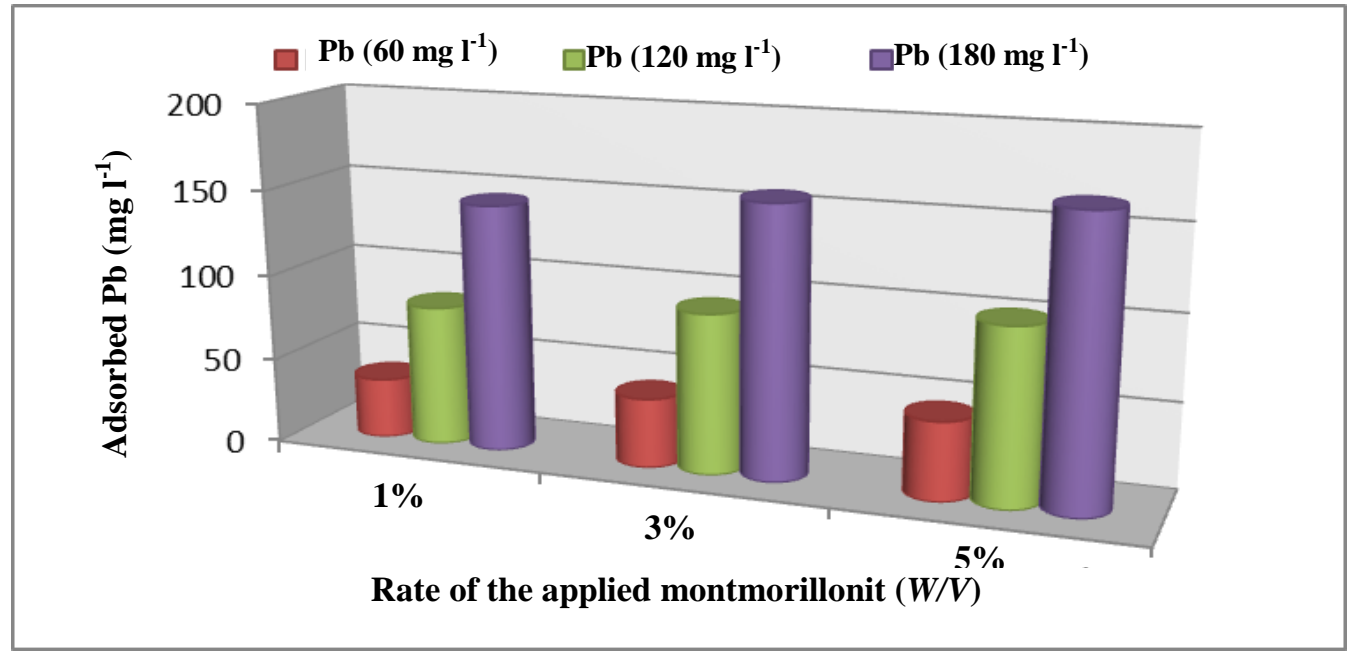

Fig. 2. Lead removal $\left(\mathrm{mg} \mathrm{l}^{-1}\right)$ by diffrent rates of montmorillonite from aqueous solutions containing different lead levels

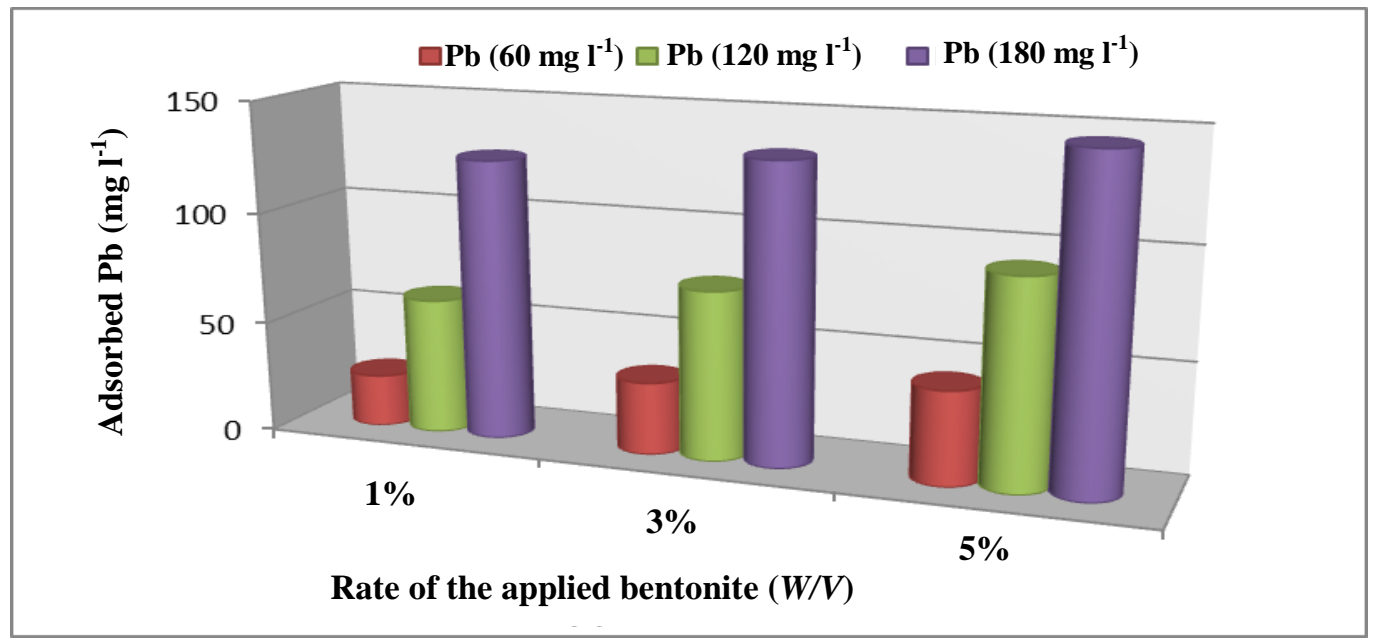

Fig. 3. Lead removal $\left(\mathrm{mg} \mathrm{l}^{-1}\right)$ by different rates of bentonite from aqueous solutions containing different lead levels

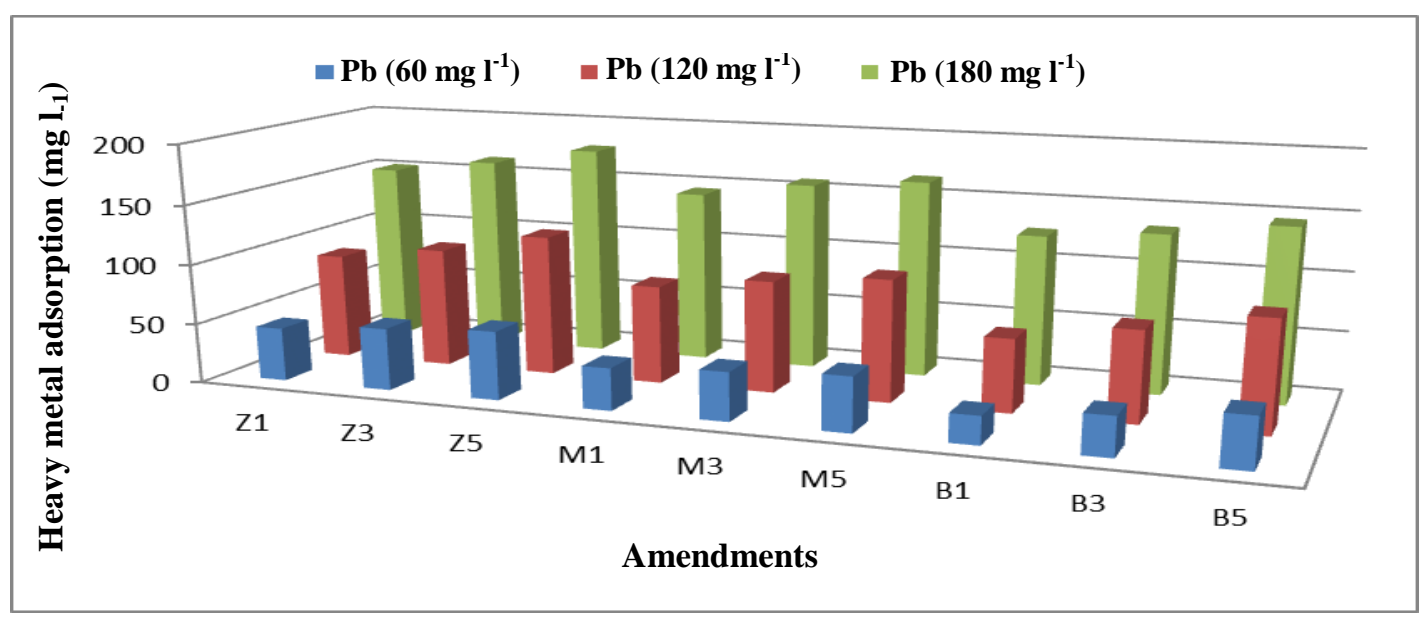

Fig. 4. Lead removal from aqueous solutions containing different lead levels at different rates of zeolite (Z), montmorillonite (M) and bentonite (B) 
The highest amount of lead adsorbed was found with zeolite followed by montmorilonite and bentonite, respectively. These results are in agreement with Wahba et al. (2016a) reported that the role of zeolite was more pronouncing in enhancing the adsorption of the heavy metals more than bentonite due its specific molecular structure and high surface area. Therefore it recommended to be applied as a remediation material in polluted soils by heavy metals.

On the other hand, Fig. 4 illustrate the concentration of element adsorbed from water as affected by three rates of zeolite, montmorillonite and bentonite (1, 3 and 5\%). wherever increased the rate of clay minerals increased the amount adsorbed of lead.

\section{Conclusions}

The contribution of the conducted experiment to evaluate the role of zeolite, montmorillonite and bentonite to eliminate the hazard of lead on contaminated water, had led to important scientific information which can be outlined in the following points:

- The role of zeolite, as a remediation material, was more effective on the adsorption of heavy metals than montmorillonite and bentonite, respectively. This was related to the specific structure of zeolite high cation exchange capacity and large surface area. However, montmorillonite and bentonite had certain properties as its ability to form thixotrophic gels with water and relatively high cation exchange capacity which allow the adsorption of heavy metals and reduce their release in liquid.

- The clay minerals are significantly minimized the rate of heavy metals release. It was obvious from the obtained results that the ability of zeolite in reducing the heavy metals release was more pronounced than montmorillonite and bentonite.

- According to results reported in this study, lead adsorption mechanisms by clay minerals may be explained as follows:

1. Vander-walls and hydrogen binding of lead with hydroxyl group of zeolite, montmorillonite and bentonite surfaces.
2. Ion exchange between $\mathrm{Pb}(\mathrm{II})$ ions and exchangeable cations ( $\mathrm{Na}, \mathrm{K}$ etc.) which balance negative charge of aluminum atoms.

Summarily, all these experimental results showed that clay minerals are suitable adsorbent for removal of heavy metals.

\section{REFERENCES}

Cottenie, A., M. Verloo, L. Kiekens, G. Velghe and R. Camerlynck (1982). Chemical Analysis of Plants and Soils. Laboratory of Analytical and Agrochemistry, state university-Ghent, Belgium.

Esmaeilpour, N.F., J. Givi and S. Houshmand (2015). The effect of zeolite,bentonite and sepiolite minerals on heavy metal uptake by sunflower. J. Sci. and Technol. Greenhouse Cult., 6: 21.

Hasanabadi, T., L. Shahram, R. Mohammad, G. Hosein and M. Adel (2015). Effect of clinoptilolite and heavy metal application on some physiological characteristics of annual alfalfa in contaminated soil. Biological Forum- An Int. J., 7 (2): 361-366

Kwon, J.S., S.T. Yun, J.H. Lee, S.O. Kim and H.Y. Jo (2010). Removal of divalent heavy metals (Cd, $\mathrm{Cu}, \mathrm{Pb}$, and $\mathrm{Zn}$ ) and arsenic (III) from aqueous solutions using scoria: kinetics and equilibria of sorption. J. Hazard Mater, 174 : 307-313.

Marzieh, H.N. (2014). The Application of zeolitein thickeners for optimal water recover and preventing environmental pollution. Recikla i odrzivirazvoj, 7: 30-34.

Mojiri, A., H.A. Aziz, L. Ziyang, Z. Nanwen, R. Tajuddin, S. Qarani and G. Dongdong (2015). Zeolite and activated carbon combined with biological treatment for metals removal from mixtures of landfill leachate and domestic waste water. J. Global NEST, 17 (4): 727-737.

Saber, M., E. Hobballa, S. El-Ashery and A.M. Zaghloul (2012). Decontamination of potential toxic elements in sewaged soils by inorganic amendments. J. Agric. Sci. Technol., 2 (11) : 1232-1244. 
Wang, S. and Y. Peng (2010). Natural zeolites as effective adsorbents in water and waste water treatment. J. Chem. Eng., 156: 11-24

Wahba, M.M., Sh.M. Shehata and A.M. Zaghloul (2012). Treatment of polluted water by clay minerals to eliminate the heavy metals. Int. J. Res. Manag., 2(3) 16:24

Wahba, M.M., B.F. Labib, Kh.M. Darwish and M.A. Zaghloul (2016a). Application of bentonite and zeolite to eliminate the hazards of cadmium, copper and nickel metals in contaminated soils. Clay Res., 35 (1): 34-42

Wahba, M.M., I.S. Rahim and M.A. Zaghloul (2016b). Application of clay minerals to decrease hazard of heavy metals in some Egyptian soils. Ame. J. Environ. and Res. Econ., 1(1): 24-31.

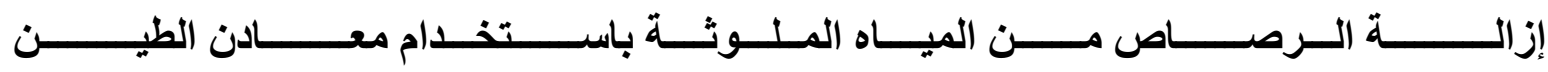

$$
\begin{aligned}
& \text { وفاء محمد حشيش' ـ فهمى محمد حبيب' ـ منير مراد وهبة' ـ عصمت حسن عطية نوفل ـ ـسرين حسين ابويكر' }
\end{aligned}
$$

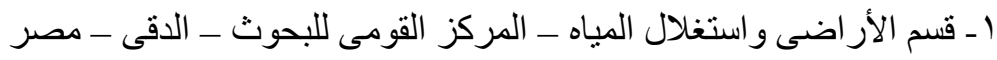

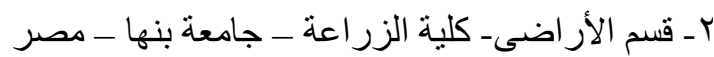

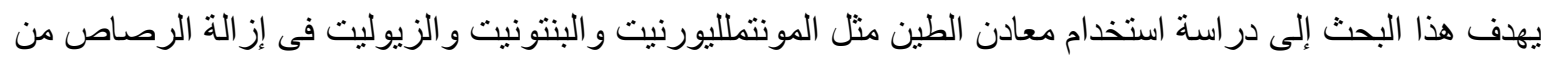

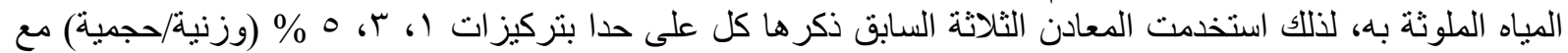

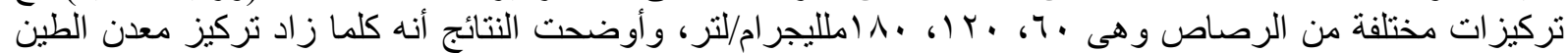

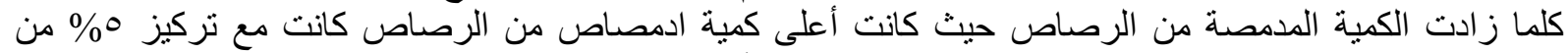

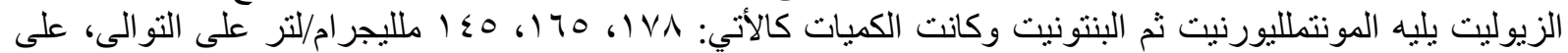

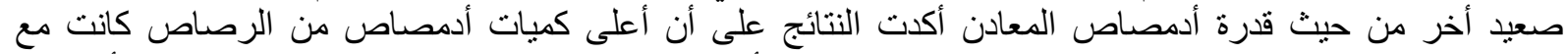

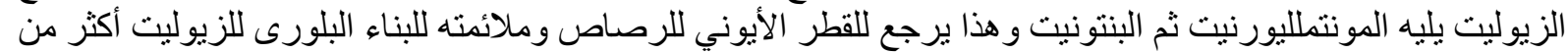

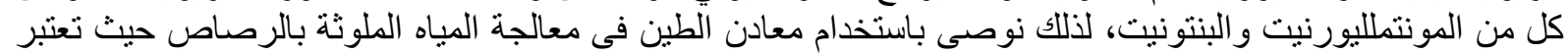

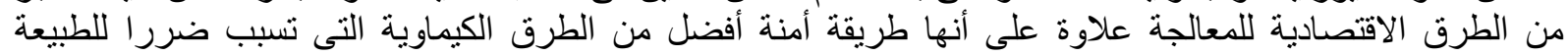

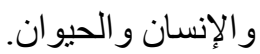

$$
\text { أستاذ ورئيس قسم الأر اضي - المركز القومي للبحوث. }
$$
أستاذ الأر اضي المتفرغ الارغية - كلية الزراعة - جامعة الزقازيق. 